\title{
The Influence of Resilience on Psychological Well-Being of Malaysian University Undergraduates
}

\author{
Izazol Idris $^{1}$, Ahmad Zamri Khairani ${ }^{2} \&$ Hasni Shamsuddin ${ }^{2}$ \\ ${ }^{1}$ Faculty of Human Development, Universiti Pendidikan Sultan Idris, Perak, Malaysia \\ ${ }^{2}$ School of Educational Studies, Universiti Sains Malaysia, Penang, Malaysia \\ Correspondence: Ahmad Zamri Khairani, School of Educational Studies, Universiti Sains Malaysia, 11800 Penang, \\ Malaysia. E-mail: ahmadzamri@usm.my
}

Received: June 27, 2019

Accepted: July 21, 2019

Online Published: July 25, 2019

doi:10.5430/ijhe.v8n4p153

URL: https://doi.org/10.5430/ijhe.v8n4p153

\begin{abstract}
Psychological well-being is fundamental to the overall health of undergraduates, particularly to enable them to address challenges at the university. A review of related literature showed that there are various factors influencing individual's psychological well-being. The purpose of this study is to investigate the influence of resilience on the psychological well-being of university undergraduates. For this purpose, a total of 200 undergraduates from local public universities $($ male $=90$, female $=110)$ participated in this exploratory study. Responses were analysed using Smart PLS 3.0 to model the influence of the two variables. Results demonstrated two significant findings. Firstly, reliable and valid adapted instruments measuring resilience and psychological well-being were established, and secondly, resilience is a significant predictor and it explained $48.2 \%$ variance in psychological well-being. The findings are discussed in relation to the development of a model that relates the two constructs.
\end{abstract}

Keywords: psychological well-being, resilience, university undergraduates

\section{Introduction}

Life at university consistently puts students under various challenges which lead to various possibilities of success or failure (Bataineh, 2013). In fact, there is an increase in the literature that concerns with well-being of both university undergraduates (Alim et al., 2016; Omar, 2010) and graduates (Roslan et al., 2017) because of the constant challenges that they have to endure. In Malaysia, undergraduates are constantly experiencing challenges relating to academic matters, personal, social and careers, as well as (the lack of) university infrastructure. For example, the study of Khairani and Effendi (2016) shows that bad internet connection is the main challenges faced by students at Universiti Sains Malaysia, followed by the challenges to have good results and being away from family. According to Yusoff (2013), poor academic performance is also a significant predictor for depression, while Lee and Syaid (2017) identified bad health habits, such as smoking and alcohol addiction, as important problems that can affect undergraduates' mental health as well.

The ability to address these challenges and flourish at university life is regarded as resilience. Resilience is a popular concept that focuses on research that transcends across various fields, particularly in psychology (Luthar, 2003; Masten \& Powell, 2003) and health (Zautra Hall \& Murray, 2010). In general, resilience is considered as an important factor that differentiates between success and failure to survive the challenges in one's life. Nevertheless, as rightly observed by Knight (2007), there is no universally accepted definition of resilience. However, the construct has been associated with positive adjustment from threat or nuisance (Everall, Altrows \& Paulson, 2006), or the ability to bounce back from adversities (Walker et al., 2006; Mercer, 2010). According to Pooley and Cohen (2010), the latter definition has been accepted as the predominant definition of resilience. According to Tugade and Frederickson (2004), a person can nurture resilience by cultivating positive emotions in order to recover from adversities. The ability to bounce back from adversities also enhances psychological well-being (Stephen 2013). Psychological well-being (PWB) is usually defines as the extent to which people live themselves to the fullest of their potentials (Ryff, 1989). PWB is an important construct since it correlates positively with adaptation to university life (Bowman, 2010), academic achievement (Chow 2007), stress (Danan \& Feng 2018) and coping strategies (Freire et al., 2016). As such, it is not unexpected that currently, PWB (and its correlates) takes the centre stage in the studies of well-being. 


\subsection{Resilience and Psychological Well-Being}

In previous studies, resilience is much more associated to academic achievement (Khalaf, 2014) as well as some other constructs about positive development such as persistence (Jin \& Kim, 2017), optimism (Souri \& Hasanirad, 2011), adjustments (Moon, Kwon \& Chung, 2015), and social intelligence (Annisa \& Ratih, 2017). In addition, previous studies viewed from the perspective of traditional psychology (Bastaminia, Hashemi, Alizadeh \& Dastoorpoor, 2016; Fatimah, 2016; Hamdan-Mansour et al., 2014; McGillivray \& Pidgeon, 2015), finds inverse relationship between resilience and level of stress, anxiety and depression of university undergraduates. Indirectly, this finding provides initial overview of the importance of resilience in developing good mental health among university undergraduates. Thus, the rapid development of positive psychology witnessed the flourishing of studies associating resilience with good mental health (Chaisang, 2017; Mello, 2016; Peng et al., 2012) and good quality of life (Momeni \& Shahbazirad, 2012; Somaiya et al., 2015) among university students. In the meantime, studies by (Chen, 2016; Kim \& Shin, 2016; Kirmani, Sharma, Anas \& Sanam, 2015) has also proven a positive relationship between resilience, happiness and satisfaction; in which the latter two are constructs that demonstrated subjective well-being.

Other than the subjective aspects of well-being such as happiness and satisfaction, students' well-being should also be assessed from the other sides of the coin, that is their ability to function optimally as a university student. This perspective defined the concept of psychological well-being (PWB), which is the focus in this study. Most of the previous studies about these two constructs have focused much on medical (Bigdeli, Najafy \& Rostami, 2013; Souri \& Hasanirad, 2011) and nursing (Abiola, Olorukooba \& Afolayan, 2017; Chow et al., 2018; Jin \& Kim, 2017) students, based on the assumption that these groups are faced with more challenges. All of these studies found that resilience has a moderate to strong and positive relationship with PWB. By that, these researchers concluded that medical and nursing students with high level of resilience would also have high levels of PWB.

In the meantime, similar results were also found in a number of fewer studies conducted on students from different programs such as social science (Denovan \& Macaskill, 2017), engineering and law (Sagone \& De Caroli, 2014), and psychology (Faircloth, 2017). Meanwhile, some other previous researchers studied the relationship between resilience and PWB among university undergraduates as a whole, not only focusing on specific programs. This is done because the challenges faced by university students are generally similar. Studies by Archana and Singh (2014), Malkoc and Yalcin (2015), Panchal et al. (2016), and Pidgeon and Keye (2014), have also found positive and significant relationship between resilience and PWB.

The highlight of the literature review is the benefits of resilience to mental health of university undergraduates, specifically on its relationship with the PWB. Nevertheless, such findings are derived from oversea studies, meanwhile in Malaysia, studies about these two constructs remain scarce. In this regard, this study was conducted to address the relationship between resilience and PB among Malaysian university undergraduates.

\subsection{Hypothesis}

The purpose of this study is to investigate the relationship between resilience and PWB among university undergraduates. Based on the findings of the previous studies reviewed in the literature, this study hypothesized that there is a positive and significant relationship between resilience and PWB.

\section{Method}

\subsection{Participants}

The sample consisted of 200 undergraduates from three local universities. Table 1 shows the demographic information of the sample. Even though the sample consists of more female undergraduates, the proportion of other important characteristics such as ethnicity, years of study, and field of study is almost similar. Purposive sampling based on the judgment of the researcher was employed for this study because of the constraints of time and cost. Data were collected during lectures to ensure good returns. Before attempting the questionnaire answering, the participants were informed about the objectives and nature of the study. The questionnaire was administered after asking the participants for their oral consent. It took about 15-20 minutes to complete the questionnaire. The participants were thanked for their participation in the study. 
Table 1. Demographic information of the participants

\begin{tabular}{ccc}
\hline Demographic & $N$ & $\%$ \\
\hline Gender & 90 & 45.0 \\
Male & 110 & 55.0 \\
Female & 53 & \\
Ethnicity & 59 & 26.5 \\
Malay & 54 & 29.5 \\
Chinese & 34 & 27.0 \\
Indian & & \\
Others & 55 & 27.0 \\
Year of Study & 58 & 29.0 \\
First & 47 & 23.5 \\
Second & 40 & 20.0 \\
Third & & \\
Final & 60 & 30.0 \\
Field of Study & 46 & 23.0 \\
Pure Science & 42 & 21.0 \\
Applied Science & 52 & 26.0 \\
Pure Arts &
\end{tabular}

\subsection{Instruments}

Undergraduate resilience was measured using a 21-item The Adolescent Resilience Scale (ARS) adapted from Oshio et al. (2002). In this instrument, resilience is conceptualised as a personality trait, which is considered as fixed and stable over time. The ARS instrument is selected because the instrument was designed for measuring resilience for the age group of 19 to 22 years, which corresponds to the context of university undergraduates in Malaysia. In ARS, resilience is being conceptualised as comprising three sub-constructs; (1) Search for Authenticity, (2) Emotion Control, and (3) Future Orientation. Conceptualisation and operationalisation of every sub-construct are given in Table 2.

Table 2. Conceptualization and operationalization of the resilience construct

\begin{tabular}{cccc}
\hline Sub-construct & Definition & $\begin{array}{c}\text { No of } \\
\text { Item }\end{array}$ & Example of Item \\
\hline Novelty seeking & $\begin{array}{c}\text { The ability to pay attention } \\
\text { and to show interest in various } \\
\text { things and events }\end{array}$ & 7 & I always look for new challenges \\
\hline Emotional regulation & $\begin{array}{c}\text { Ability to calm down and } \\
\text { control internal emotions. }\end{array}$ & 9 & I believe I can control my emotion \\
\hline Positive future orientation & $\begin{array}{c}\text { The ability to have future } \\
\text { purpose and prospect as well } \\
\text { as believing that they are } \\
\text { achievable }\end{array}$ & 5 & I have a clear future purpose \\
& & &
\end{tabular}

The ARS was translated into the Malay Language using the back-to-back translation procedure. The instrument was first translated into the Malay Language. Then, the instrument was translated back into English. The translation was conducted by two certified translators. Apart from the translation into the Malay Language, the original item was also modified into having six categories of 1 - Strongly Disagree, 2 - Disagree, 3 - Less Agree, 4 - Quite Agree, 5 Agree, and 6 - Strongly Agree from the original five categories. This modification was done because the use of a 6-point Likert scale allows more variations and enable participants to provide more thorough responses.

Meanwhile, the participants' PWB was measured using the Flourishing Scale (FS) (Diener et al., 2009). The FS measures individual function, which was conceptualised by eight items. For example, one's meaning and purpose of 
life are measured using the following item: I lead a purposeful and meaningful life. The FS originally employed a seven-category response scale. However, for this study, only the six categories of 1 - Strongly Disagree, 2 - Disagree, 3 - Less Agree, 4 - Quite Agree, 5 - Agree, and 6 - Strongly Agree were utilised. The category of "not sure" was dropped to ensure that the participants would not choose the category in which they did not understand the statement (Bond \& Fox, 2015).

\subsection{Data Analysis}

The purpose of this study is to predict the influence of resilience on PWB among Malaysian university undergraduates. As such, the study employed variance based partial-least-square structural equation modelling (PLS-SEM) using SmartPLS 3.0 software. The main objective of this PLS-SEM analysis is to maximise the variance in the PWB, which is explained by resilience. Therefore, the analysis is more suitable for predicting latent variable as intended in this study. Reinarts, Haenlein, and Henseler (2009) further clarified that PLS-SEM is more appropriate for model development for the purpose of exploring and predicting, as well as identification of the best prediction for the relationship between variables. In addition, the researchers adopted the PLS-SEM analysis since the number of undergraduates in this study is small. Also, according to Avkiran (2017), PLS-SEM is more robust towards non-normal data distribution.

In this study, the adequacy of the prediction was assessed in two-phase; (1) the measurement model, and (2) the structural model. The measurement model demonstrates the relationship between measuring items and their underlying latent constructs (resilience and PWB). In this study, the reflective measurement model was used where the direction of causality is conceptualised from the construct to the indicators (items). Therefore, a change in the construct will cause changes in the indicators (Jarvis, Mackenzie \& Podsakoff, 2003). Evaluation of the measurement model was based on three aspects of internal reliability, convergent validity, and discriminant validity. This study used Cronbach's $\alpha$ as well as composite reliability as the indicators for internal consistency. Cronbach's $\alpha$ is one of the most widely used statistics for internal reliability. It estimates the reliability based on the inter-correlation of item. Meanwhile, the composite reliability is also widely used since the statistics takes into account that all items have different loadings (Chin, 1998). That is, in contrast to Cronbach's $\alpha$, composite reliability assumes that all items have different outer loadings. Convergent validity relates to the extent to which the items are related to each other (Chin, 2010). High value of item loading with low cross loading is an example of good convergent validity. Apart from the item loadings, the average variance extracted (AVE) is also a widely used statistics to provide evidence of convergent validity. The value of AVE is calculated by summing up the squared loadings and then dividing them by the number of items (Hair et al., 2014). Meanwhile, discriminant validity refers to the extent to which the items are different from other (Henseler, 2017). Chin (2010) quotes that a construct should closely associate with items more than to other items that measure different constructs. In this study, the Fornell-Lacker criterion (Fornell \& Larcker, 1981) was employed to evaluate the discriminant validity of the measurement model. In order to show satisfactory evidence of discriminant validity, the square root of AVE of a particular construct must be higher than the correlation between constructs. The indicators and their cut-off values for these aspects are given in Table 3. Definitions for the indicators, however, are excluded in this short description. Interested readers may refer to various books, especially by Hair et al. (2011), which further explain these terms in more detail.

Table 3. Criteria for evaluation of the measurement model

\begin{tabular}{|c|c|c|c|}
\hline Aspect & Indicator & Cutoff values & Reference \\
\hline \multirow{2}{*}{$\begin{array}{l}\text { Internal } \\
\text { reliability }\end{array}$} & Cronbach's $\alpha$ & $\alpha \geq 0.60$ & Hair et al. (2017) \\
\hline & $\begin{array}{l}\text { Composite } \\
\text { reliability, CR }\end{array}$ & $\mathrm{CR} \geq 0.60$ & $\begin{array}{l}\text { Bagozzi and Yi } \\
\text { (1988) }\end{array}$ \\
\hline \multirow{5}{*}{$\begin{array}{c}\text { Convergent } \\
\text { validity }\end{array}$} & Item factor loadings, & $\lambda \geq 0.70$ (maintained) & Hair et al. (2017) \\
\hline & $\lambda$ & $\begin{array}{c}0.40 \geq \lambda \leq 0.70 \text { (drop the items only if there is an } \\
\text { increase in CR dan AVE) }\end{array}$ & \\
\hline & & $\lambda<0.40$ (dropped the items from further analysis) & \\
\hline & Average variance & $\mathrm{AVE} \geq 0.50$ & Hair et al. (2017) \\
\hline & $\begin{array}{l}\text { extracted, } \\
\text { AVE }\end{array}$ & The value so $\mathrm{AVE}<0.50$, is accepted if $\mathrm{CR} \geq 0.60$ & \\
\hline $\begin{array}{l}\text { Discriminant } \\
\text { validity }\end{array}$ & $\begin{array}{l}\text { Fornell-Lacker } \\
\text { criterion }\end{array}$ & $\begin{array}{l}\text { The square root of AVE of a particular construct must } \\
\text { be higher than the correlation between constructs. }\end{array}$ & $\begin{array}{c}\text { Fornell and } \\
\text { Larcker (1981) }\end{array}$ \\
\hline
\end{tabular}


Urbach and Ahleman (2010) urged that when the measurement model shows evidence of high reliability and validity, researchers need to examine whether the empirical data supported the hypotheses conceptualised in the structural model. Assessment of the structural model includes examining the predictive ability of the model as well as relationship between constructs. In this study, the structural model evaluated from three aspects, namely, collinearity, strength of the relationship between constructs and variance explained by the exogenous (independent) constructs. Collinearity relates to the phenomenon of high correlation between two constructs. As such, researchers need to examine the level of collinearity before assessing the structural model (Hair et al., 2014). In this study, the collinearity issue was addressed by examining the Variance Inflation Factor (VIF) statistic. According to Kock and Lynn (2012), the value of more than 5.00 indicates a possible threat of collinearity. If this happens, the researcher will need to consider either eliminating the constructs, merging the items, or creating higher-order constructs (Hair et al., 2014). Meanwhile, assessment of path coefficients, $\beta$ s, relates the issue of hypothesised relationship between constructs. The standardised estimate of $\beta$ ranges between -1.0 to +1.0 , with the positive value implies that an increase in one construct leads to the decrease of the exogenous construct. In contrast, the negative value indicates that an increase in one construct leads to the decrease in the exogenous construct. Meanwhile, higher values of $\beta$ indicate a stronger relationship between the constructs, and vice versa. The variance is explained by the exogenous construct (resilience) on the endogenous construct (PWB). In this study, the $\mathrm{R}^{2}$ values of the PWB were employed as the basis to evaluate the adequacy of the structural model. The value of $\mathrm{R}^{2}$ ranges from 0 to 1 , in which higher value indicates higher predictive accuracy of the exogenous construct (Hair et al., 2014). Table 4 shows the indicators for assessment of structural model and their cut-off values.

Table 4. Criteria for evaluation of the structural model

\begin{tabular}{|c|c|c|c|}
\hline Criteria & Indicator & Cutoff Values & Reference \\
\hline Collinearity & $\begin{array}{c}\text { Variance } \\
\text { Inflation Factor, } \\
\text { VIF }\end{array}$ & $<5.00$ & $\begin{array}{l}\text { Kock and Lynn } \\
\text { (2012) }\end{array}$ \\
\hline $\begin{array}{c}\text { The strength of relationship } \\
\text { between resilience and } \\
\text { PWB }\end{array}$ & $\begin{array}{c}\text { Path coefficient, } \\
\beta\end{array}$ & Equal or above .20 & Hair et al. (2014) \\
\hline $\begin{array}{l}\text { Variance explained by the } \\
\text { exogenous constructs }\end{array}$ & $\begin{array}{l}\text { Coefficient of } \\
\text { determination, } \\
\mathrm{R}^{2}\end{array}$ & $\begin{array}{c}.67 \text { substantial, } .33 \text { moderate } \\
\& .19 \text { weak }\end{array}$ & Hair et al. (2017) \\
\hline
\end{tabular}

\section{Results}

Table 5 shows item factor loadings $(\lambda)$, Cronbach's $\alpha$ composite reliability (CR) and average of variance explained (AVE) for the measurement model. It is crucial to highlight that several items were dropped from further analysis because of their low item factor loadings. More specifically, two items (R16 and R18) were dropped from novelty seeking and five items (R14, R17, R19, R20, and R21) were dropped from emotional regulation. However, no items were dropped from the positive future orientation sub-construct and PWB. The Cronbach's $\alpha$, CR and AVE showed satisfactory values, except for the AVE of the emotional regulation subconstruct, thus providing evidence of the adequacy of the items in measuring both the resilience and PWB constructs. With regards to the discriminant validity, as depicted in Table 6, it is clear that the square root of AVE from each subconstruct is greater than its correlation with other subconstructs in the measurement model. For example, the square root of AVE for the novelty seeking subconstruct (0.75) is greater than its correlation with emotional regulation (0.67), positive future orientation (0.67), and PWB (0.61). 
Table 5. The measurement model

\begin{tabular}{|c|c|c|c|c|c|}
\hline Sub-construct & Item & $\lambda$ & Cronbach's $\alpha$ & $C R$ & $A V E$ \\
\hline \multirow[t]{5}{*}{ Novelty seeking } & $\mathrm{R} 1$ & 0.67 & \multirow[t]{5}{*}{0.80} & \multirow[t]{5}{*}{0.86} & \multirow[t]{5}{*}{0.56} \\
\hline & $\mathrm{R} 4$ & 0.81 & & & \\
\hline & $\mathrm{R} 7$ & 0.78 & & & \\
\hline & $\mathrm{R} 10$ & 0.78 & & & \\
\hline & $\mathrm{R} 13$ & 0.67 & & & \\
\hline \multirow{4}{*}{$\begin{array}{l}\text { Emotional } \\
\text { regulation }\end{array}$} & $\mathrm{R} 2$ & 0.56 & \multirow[t]{4}{*}{0.61} & \multirow[t]{4}{*}{0.77} & \multirow[t]{4}{*}{0.46} \\
\hline & $\mathrm{R} 5$ & 0.75 & & & \\
\hline & $\mathrm{R} 8$ & 0.69 & & & \\
\hline & $\mathrm{R} 11$ & 0.69 & & & \\
\hline \multirow{5}{*}{$\begin{array}{l}\text { Positive future } \\
\text { orientation }\end{array}$} & R3 & 0.76 & \multirow[t]{5}{*}{0.82} & \multirow[t]{5}{*}{0.87} & \multirow[t]{5}{*}{0.58} \\
\hline & R6 & 0.79 & & & \\
\hline & R9 & 0.84 & & & \\
\hline & $\mathrm{R} 12$ & 0.77 & & & \\
\hline & $\mathrm{R} 15$ & 0.63 & & & \\
\hline \multirow[t]{8}{*}{ PWB } & K1 & 0.77 & \multirow[t]{8}{*}{0.88} & \multirow[t]{8}{*}{0.90} & \multirow[t]{8}{*}{0.54} \\
\hline & $\mathrm{K} 2$ & 0.79 & & & \\
\hline & K3 & 0.64 & & & \\
\hline & K4 & 0.79 & & & \\
\hline & K5 & 0.71 & & & \\
\hline & K6 & 0.77 & & & \\
\hline & K7 & 0.75 & & & \\
\hline & K8 & 0.67 & & & \\
\hline
\end{tabular}

Table 6. The Fornel-Lacker criterion

\begin{tabular}{ccccc}
\hline & $\begin{array}{c}\text { Novelty } \\
\text { seeking }\end{array}$ & $\begin{array}{c}\text { Emotional } \\
\text { regulation }\end{array}$ & $\begin{array}{c}\text { Positive future } \\
\text { orientation }\end{array}$ & PWB \\
\hline Novelty seeking & $\mathbf{0 . 7 5}$ & & & \\
Emotional regulation & 0.67 & $\mathbf{0 . 6 8}$ & $\mathbf{0 . 7 6}$ & \\
Positive future orientation & 0.67 & 0.59 & 0.66 & $\mathbf{0 . 7 4}$ \\
PWB & 0.61 & 0.51 & 0.66
\end{tabular}

Meanwhile, results for assessment of the structural model are given in Table 7. The value of VIF in this study is 1.00 , which is below 5.00. Therefore, the correlation between the two constructs is considered at a tolerable level. The path coefficient between resilience and PWB, $\beta$, shows a hypothesised relationship between the two variables. A high value of $\beta$ shows a close relationship and vice versa. In this study, the value of $\beta$ is 0.69 , which is higher than the cut-off value of 0.20 . The data showed that resilience also explained a moderate $43 \%$ variance in PWB of the undergraduates based on the $\mathrm{R}^{2}$ value.

Table 7. The structural model

\begin{tabular}{ccc}
\hline Indicator & Cutoff Values & Empirical values \\
\hline VIF & $<5.00$ & 1.00 \\
Path coefficient, $\beta$ & Equal or above .20 & 0.69 \\
Coefficient of determination, & .67 substantial, .33 moderate \& .19 weak & 0.43 \\
$\mathrm{R}^{2}$ & & \\
\hline
\end{tabular}




\section{Discussion}

Findings of the present study are discussed in two stages. Firstly, the adequacy of the measurement model is elaborated and this is followed by a discussion on the influence of resilience on PWB. In addition, suggestions on how to improve resilience and PWB are also put forward at the end of the section.

With regards to the measurement model, the researchers have shown that a total of seven items from the ARS needed to be deleted from further analysis. This was because the items showed low item factor loadings which indicated that the meaning of the items are not consistent with the construct they reflect (Urbach \& Ahlemann 2010). Nevertheless, the deletion of the items did not compromise the content validity of the instrument since there are other items that fulfilled the purpose of measuring the construct of resilience. The inability of the items to function as intended is not unexpected since resilience, like any other psychological constructs, is known to be context specific. That is, its meaning is influenced by how the sample in a particular context sees the items. For example, the study by Oladipo and Idemudia (2015) found that three of the original 25-item Resilience Scale (Wagnild \& Young, 1993) did not perform as expected in the Nigerian sample. Similarly, Ruvalcaba-Romero, Gallegos-Guajardo, and Villegas-Guinea (2015) deleted six items from the original 28 items of the Resilience Scale for Adolescents because of the low item factor loadings for the sample of Mexican adolescents.

As for the structural model, the result was rather expected despite a lack of studies concerning resilience and PWB among undergraduates. The present findings indicate that resilience significantly correlates in a positive direction with PWB. That is, the higher the resilience, the higher the PWB will be. The results also revealed that resilience accounts for $48.2 \%$ variance in PWB. Therefore, this study concludes that resilience is a good predictor of student's PWB. This present finding is consistent with Panchal, Mukherjee, and Kumar (2016), who demonstrated a similar relationship between resilience and students' PWB from a university in India. The current finding is also consistent with Pidgeon and Keye (2014), who examined the relationship between resilience and PWB among Australian university undergraduates, and found that resilience accounting for the greatest amount of $47 \%$ variance in PWB. Similar results were also demonstrated among university undergraduates in India (Archana \& Singh, 2014), Iran (Bigdeli, Najafy \& Maryam, 2013; Souri \& Hasanirad 2011), and South Korea (Jin \& Kim, 2017).

Meanwhile, the results suggest that both constructs are influencing each other. Therefore, there is a need for university stakeholders to find ways to improve both constructs such as by developing programmes that target cultivating resilience (Pidgeon \& Keye 2014) and providing social supports (Pooley \& Cohen, 2010) to increase students' ability to effectively manage complex challenges and face demands of university life. This is to encourage undergraduates to share their adversities not only for assistance but also for releasing their psychological burden due to the problems they face. As for undergraduates, social support can be found in the form of joining groups at the university or engaging in activities. Resilience can also be built and improved if undergraduates are able to keep things according to their perspectives. For example, when facing challenges, it is perhaps good for them to take a step back so that they are able to see the challenges from a bigger or different perspective. For example, they may want to question whether the challenges require immediate and prompt action, or it can be addressed in a more appropriate time or when greater opportunity arrives. Similarly, undergraduates should make a habit of looking back on all that they have accomplished so that they have the belief in their ability to bounce back.

\section{Conclusion}

This present study demonstrates that there is a significant relationship between resilience and PWB among them. Consequently, there is a need to improve undergraduates' resilience so that they can improve their PWB. The results also suggest that improving undergraduates' PWB will also reciprocally strengthen their ability to bounce back from adversities. The effort to explore this relationship is based on the construction of a measurement and the structural model that provides evidence of the validity and reliability of the instruments used.

\section{Acknowledgements}

This study was made possible through Universiti Sains Malaysia Bridging Grant 304.PGURU.6316012

\section{References}

Alim, A. A. Cassandra, C., Rathakrishnan, B., Alim, A. \& Voo, P. (2016). Relationship of perfectionism and basic psychological needs to psychological well-being among university students at university in Sabah, Malaysia. Jurnal Psikologi Malaysia, 30, 113-21.

Annisa A. \& Ratih A.L. (2017). Peran kecerdasan sosial terhadap resiliensi pada mahasiswa tingkat awal. Psympathic-Jurnal Ilmiah Psikologi, 4(1), 67-90. https://doi.org/10.15575/psy.v4i1.1261 
Archana, U. K. \& Singh, R. (2014). Resilience and spirituality as predictors of psychological well-being among university students. Journal of Psychosocial Research, 9(2), 227-235.

Avkiran, N. K. (2017). An in-depth discussion and illustration of partial least squares structural equation modelling in health care. Health Care Management Science, 21(3), 401-408. https://doi.org/10.1007/s10729-017-9393-7

Baek, H., Lee, K., Joo, E., Lee, M. \& Choi. K. (2010). Reliability and validity of the Korean version of the $\begin{array}{lllll}\text { Connor-Davidson } & \text { resilience } & \text { scale. Psychiatry Investigation, } & 7(2), & 109-115 .\end{array}$ https://doi.org/10.4306/pi.2010.7.2.109

Bagozzi, R. \& Yi, Y. (1988). On the evaluation of structural equation models. Journal of the Academy of Marketing Sciences, 16, 74-94. https://doi.org/10.1007/BF02723327

Bastaminia, A., Hashemi, F. B. \& Alizadeh, M. (2016). Resilience and mental health: A study among students at the State University of Yasuj City. Britihs Journal of Education, Society \& Behavioural Science, 18(2), 1-9. https://doi.org/10.9734/BJESBS/2016/28885

Bataineh, M. Z. (2013). Academic stress among undergraduate students: The case of education faculty at King Saud University. International Interdisciplinary Journal of Education, 2(1), 82-88. https://doi.org/10.12816/0002919

Bigdeli, I., Najafy, M. \& Maryam, R. (2013). The relation of attachment styles, emotional regulation and resilience to well-being among students of medical sciences. Iranian Journal of Medical Education, 13(9), 721-729.

Bond, T. G. \& Fox, C. M. (2015). Applying the Rasch Model Fundamental Measurement in the Human Sciences (3rd ed.). Mahwah, NJ L. Erlbaum. https://doi.org/10.4324/9781315814698

Bowman, N. A. (2010). The development of psychological well-being among first-year college students. Journal of College Student Development, 51(2), 180-200. https://doi.org/10.1353/csd.0.0118

Burns, R. A., Anstey, K. J. \& Windsor, T. D. (2011). Subjective well-being mediates the effects of resilience and mastery on depression and anxiety in a large community sample of young and middle-aged adults. Australian and New Zealand Journal of Psychiatry, 45(3), 240-248. https://doi.org/10.3109/00048674.2010.529604

Chaisang, U. (2017). Resilience and mental health among students at Sirindhorn College of Public Health Yala. Paper presented at the Academic Cluster International Spring Conferences. Retrieved from http://www.universal-conferences.org/proceedings/2017/spring

Chen, C. (2016). The role of resilience and coping styles in subjective well-being among Chinese university students. Asia-Pacific Education Researcher, 25(3), 377-387. https://doi.org/10.1007/s40299-016-0274-5

Chin, W. W. (1998). The partial least squares approach for structural equation modelling. In Modern Method for Business Research. Edited by George A. Marcoulides. Mahwah: Lawrence Erlbaum Associates, 295-336.

Chin, W. W. (2010). How to write up and report PLS analyses. In Handbook of Partial Least Squares: Concepts, Methods, and Applications in Marketing and Related Fields, Edited by Vincenzo Esposito Vinzi, Wynne W. Chin, Jörg Henseler, Huiwen Wang. Berlin: Springer, 655-690. https://doi.org/10.1007/978-3-540-32827-8_29

Chow, K. M., Tang, W. K. F., Chan, W. H. C., Sit, W. H. J., Choi, K. C. \& Sally, C. (2018). 2018. Resilience and well-being of university nursing students in Hong Kong: A cross-sectional study. BMC Medical Education, 18, 13. https://doi.org/10.1186/s12909-018-1119-0

Chow, P. H. H. (2007). Psychological well-being and scholastic achievement among university students in a Canadian Prairie city. Social Psychology of Education, 10(4), 483-493. https://doi.org/10.1007/s11218-007-9026-y

Danan, G. \& Feng, Q. (2018). Psychological resilience of Chinese centenarians and its associations with survival and health: A fuzzy set analysis. The Journals of Gerontology Series B: Psychological Sciences and Social Sciences, 73(5), 880-889.

Denovan, A. \& Macaskill, A. (2017). Stress, resilience, and leisure coping among university students: Applying the broaden-and-build theory. Leisure Studies, 36(6), 852-865. https://doi.org/10.1080/02614367.2016.1240220

Diener, E., Suh., E. M., Lucas, R. E. \& Smith, H. L. (2009). 1999. Subjective well-being: Three decades of progress. Psychological Bulletin, 125(2), 276-302. https://doi.org/10.1037//0033-2909.125.2.276

Ebrahimi, A., Keykhosrovani, M., Dehghani, M. \& Javdan, M. (2012). Investigating the relationship between resiliency, spiritual intelligence and mental health of a group of undergraduate students. Life Science Journal, 9(1), 67-70. 
Everall, R. D., Altrows, K. J. \& Paulson, B. L. (2006). Creating a Future: A Study of Resilience in Suicidal Female $\begin{array}{llllll}\text { Adolescents. Journal of Counselling \& Development, } & 84, & \text { 461-470. }\end{array}$ https://doi.org/10.1002/j.1556-6678.2006.tb00430.x

Faircloth, A. L. (2017). Resilience as a mediator of the relationship between negative life events and psychological well-being (unpublished doctoral thesis). Retrieved from https://digitalcommons.georgiasouthern.edu/cgi/viewcontent.cgi?article=2450\&context=etd

Fatimah, A. (2017). Pengaruh resiliensi terhadap distres psikologis pada mahasiswa. Jurnal Ilmiah Psikologi Terapan, $5(1), 80-96$

Fornell, C. D. \& Lacker, D. F. (1981). Evaluating structural equation models with unobservable variables and measurement error. Journal of Marketing Research, 18, 39-50. https://doi.org/10.1177/002224378101800104

Freire, C., Del Mar Ferradás, M., Valle, A., Núñez, J. C. \& Vallejo, G. (2016). Profiles of psychological well-being and coping strategies among university students. Frontiers in Psychology, 7 , https://doi.org/10.3389/fpsyg.2016.01554

Gibbons, C., Dempster, M. \& Moutray, M. (2011). Stress, coping and satisfaction in nursing students. Journal of Advanced Nursing, 67(3), 621-632. https://doi.org/10.1111/j.1365-2648.2010.05495.x

Haddadi, P. \& Besharat, M. A. (2010). Resilience, vulnerability and mental health. Procedia - Social and Behavioral Sciences, 5, 639-642. https://doi.org/10.1016/j.sbspro.2010.07.157

Hair, J. F., Hult, G. T. M., Ringle, C. M. \& Sarstedt, M. (2017). A Primer on Partial Least Squares Structural Equation Modeling. 2nd Ed. Thousand Oaks: Sage. https://doi.org/10.15358/9783800653614

Hair, J. F., Ringle, C. M. \& Sarstedt, M. (2011). PLS-SEM: Indeed a silver bullet. Journal of Marketing Theory and Practice, 19(2), 139-151. https://doi.org/10.2753/MTP1069-6679190202

Hair, J., Hult, T., Ringle, C. \& Sarstedt, M. (2014). A primer on partial least squares structural equation modeling (PLS-SEM). Thousand Oaks, CA: Sage.

Hamdan-Mansour, A. M., Azzeghaiby, S. N., Alzoghaibi, I. N., Al-Badawi, T. H., Nassar, O. S. \& Shaheen, A. M. (2014). Correlates of resilience among university students. American Journal of Nursing Research, 2(4), 74-79

Hartley, M. T. (2011). Examining the relationships between resilience, mental health, and academic persistence in undergraduate college students. Journal of American College Health, 59(7), 596-604. https://doi.org/10.1080/07448481.2010.515632

Hayter, M. R. \& Dorstyn, D. (2014). Resilience, self-esteem and self-compassion in adults with spina bifida. Child Abuse \& Neglect, 52(2), 167-171. https://doi.org/10.1038/sc.2013.152

Henseler, J. (2017). Bridging design and behavioral research with variance-base structural equation modeling. Journal of Advertising, 46(1), 178-192. https://doi.org/10.1080/00913367.2017.1281780

Jarvis, C. B., Mackenzie, S. B. \& Podsakoff, P. M. (2003). A critical review of construct indicator and measurement model misspecification in marketing and consumer research. Journal of Consumer Research, 30(2), 199-218. https://doi.org/10.1086/376806

Jin, J. I. \& Kim, N. C. (2017). Grit, academic resilience and psychological well-being in nursing students. Journal of Korean Academic Society of Nursing Education, 23(2), 1175-183. https://doi.org/10.5977/jkasne.2017.23.2.175

Khairani, A. Z. \& Effendi, M. M. M. (2016). Assessing challenges among university undergraduates: A case of Universiti Sains Malaysia. Advanced Science Letters, 23(4), 2894-2897. https://doi.org/10.1166/asl.2017.7597

Khalaf, M. A. (2014). Validity and reliability of the Academic Resilience Scale in Egyptian context. Us-China Education Review, 4(3), 202-210

Kim, B. \& Shin, S. (2016). Influence of happiness and ego-resilience on department satisfaction in college students. India Journal of Science and Technology, 9(43), 1-6. https://doi.org/10.17485/ijst/2016/v9i43/105041

Kirmani, M. N., Sharma, P., Anas, M. \& Sanam, R. (2015). Hope, resilience and subjective well-being among college going adolescent girls. International Journal of Humanities \& Social Science Studies, 2(1), 262-270

Knight. C. (2007). A resilience framework: Perspectives for educators. Health Education, 107(6), 543-555. https://doi.org/10.1108/09654280710827939

Kock, N. \& Lynn, G. (2012). Lateral collinearity and misleading results in variance-based SEM: An illustration and 
recommendations. Journal of the Association for Information Systems, 13(7), 546-580. https://doi.org/10.17705/1jais.00302

Kwek, A., Bui, H. T., Rynne, J. \& So, K. K. F. (2013). Academic performance: An investigation of domestic and international hospitality and tourism undergraduate students. Journal of Hospitality \& Tourism Education, 25(3), 110-122. https://doi.org/10.1080/10963758.2013.826946

Lee, M. F., Syaid, S. (2017). Factors contributing towards Malaysian technical university (MTU) students' mental health. Pertanika Journal of Social Science \& Humanities, 25(S), 93-100.

Lei, M., Li, C., Xiao, X., Qiu, J., Dai, Y. \& Zhang, Q. (2012). Evaluation of the psychometric properties of the Chinese version of the resilience scale in Wenchuan earthquake survivors. Comprehensive Psychiatry, 53(5), 616-622. https://doi.org/10.1016/j.comppsych.2011.08.007

Luthar, S. S., Cicchetti, D. \& Becker, B. (2000). The construct of resilience: A critical evaluation and guidelines for future work. Child Development, 71(3), 543-562. https://doi.org/10.1111/1467-8624.00164

Mak, W. W. S., Ng, I., S. W. \& Wong, C. C. Y. (2011) Resilience: Enhancing well-being through the positive cognitive triad. Journal of Counseling Psychology, 58(4), 610-617. https://doi.org/10.1037/a0025195

Malkoc, A. \& Yalcin, I. (2015). Relationships among resiliene, social support, coping and psychological well-being among university students. Turkish Psychological Counseling and Guidance Journal, 5(43), 35-43

Masten, A. S. \& Powell, J. L. (2003). A resilience framework for research, policy, and practice. In S. S. Luthar (Ed.), Resilience and vulnerability: Adaptation in the context of childhood adversities, 1-25. New York, NY, US: Cambridge University Press. https://doi.org/10.1017/CBO9780511615788.003

McGillivray, C. J. \& Pidgeon, A. M. (2015). Resilience attributes among university students: A comparative study of psychological distress, sleep disturbances and mindfulness. European Scientific Journal, 11(5), 33-48.

Mello, J. (2016). Life adversity, social support, resilience, and college student mental health (unpublished master's thesis). Retrieved from https://digitalcommons.cwu.edu/etd/347/

Mercer. D. (2010). Disaster risk reduction or climate change adaptation: Are we reinventing the wheel? Journal of International Development, 22(2), 247-264. https://doi.org/10.1002/jid.1677

Momeni, K. \& Shahbazirad, A. (2012). Relationship of spirituality, resiliency, and coping strategies with quality of life in university students. Journal of Behavioural Sciences, 6(2), 97-103.

Moon, W., Kwon, M. \& Chung, K. (2015). Influence of academic resilience, self-efficacy and depression on college life adjustment in Korea's nursing college students. Indian Journal of Science and Technology, 8(19), 1-4. https://doi.org/10.17485/ijst/2015/v8i19/77003

Oladipo, S. E. \& Idemudia, E. S. (. 2015). Reliability and validity testing of Wagnild and Young's Resilience Scale in a sample of Nigerian youth. Journal of Psychology, 6(1), 57-65. https://doi.org/10.1080/09764224.2015.11885524

Omar, N. E. (2010). Kesejahteraan psikologi dalam kalangan pelajar IPTS (Psychological well-being among IPTS students) Retrieved from http://www.mara.gov.my/c/document_library/get_file?uuid=2fb66357-1d33-4f9f-851e26ed93d0ec4a\&groupId $=30564$

Oshio, A., Nakaya, M., Kaneko, H. \& Nagamine, S. (2002). Development and validation of the Adolescent Resilience Scale. Japanese Journal of Counseling Science, 35, 57-65. https://doi.org/10.1037/t07520-000

Panchal, S., Mukherjee, S. \& Kumar, U. (2016). Optimism in relation to well-being, resilience, and perceived stress. International Journal of Education and Psychological Research, 5(2), 1-6.

Peng, L., Zhang, J., Li, M., Li, P., Zhang, Y., Zuo, X. \& Xu, Y. (2012). Negative life events and mental health of Chinese medical students: The effect of resilience, personality and social support. Psychiatry Research, 196, 138-141. https://doi.org/10.1016/j.psychres.2011.12.006

Pidgeon, A. M. \& Keye, M. (2014). Relationship between resilience, mindfulness, and psychological well-being in university students. International Journal of Liberal Arts and Social Science, 2(5), 27-32.

Pooley, J. \& Cohen, L. (2010). Resilience: A definition in context. Australian community Psychologist, 22(1), 30-37.

Reinarts, W. J., Haenlein, M. \& Henseler, J. (2009). An empirical comparison of the efficacy of the covariance-based 
and variance-based SEM. International Journal of research in Marketing, 26(4), 332-344. https://doi.org/10.1016/j.ijresmar.2009.08.001

Roslan, S., Norlida., Nurulain, N. \& Zeinab, G. (2017). Psychological well-being among postgraduate students. Acta Medica Bulgaria, 44(1), 35-41. https://doi.org/10.1515/amb-2017-0006

Rossi, N. E., Bisconti, T. L. \& Bergeman, C. S. (2007). The role of dispositional resilience in regaining life satisfaction after the loss of a spouse. Death Studies, 31(10), 863-883. https://doi.org/10.1080/07481180701603246

Ruvalcaba-Romero, N. A., Gallegos-Guajardo, J. \& Villegas-Guinea, D. (2015). Validation of the resilience scale for adolescents (READ) in Mexico. Journal of Behavior, Health \& Social, 6(2), 21-34. https://doi.org/10.22201/fesi.20070780.2014.6.2.48555

Ryff, C. D. (1989). Happiness is everything, or is it? Explorations on the meaning of psychological well-being. Journal of Personality and Social Psychology, 57(6), 1069-1081. https://doi.org/10.1037/0022-3514.57.6.1069

Sagone, E. \& De Caroli, M. E. (2014). Relationships between psychological well-being and resilience in middle and late adolescents. Procedia - Social and Behavioral Sciences, 141, 881-887. https://doi.org/10.1016/j.sbspro.2014.05.154

Singh, K. \& Yu, X. (2010). Psychometric evaluation of the Connor- Davidson resilience scale (CD-RISC) in a sample of Indian students. Journal of Psychology, 1(1), 23-30. https://doi.org/10.1080/09764224.2010.11885442

Somaiya, M., Faye, A., Kamath, R. \& Kolpakwar, S. (2015). Study of mechanisms of coping, resilience and quality of life in medical undergraduates. Indian Journal of Social Psychiatry, 31(1), 19--28. https://doi.org/10.4103/0971-9962.161995

Souri, H. \& Hasanirad, T. (2011). 2011. Relationship between resilience, optimism and psychological well-being in students of medicine. Procedia - Social and Behavioral Sciences, 30, 1541-1544. https://doi.org/10.1016/j.sbspro.2011.10.299

Stephens, T. M. (2013). Nursing student resilience: a concept clarification. Nursing Forum, 48(2), 125-133. https://doi.org/10.1111/nuf.12015

Tugade, M. M. \& Frederickson, B. L. (2004). Resilience individuals use positive emotions to bounce back from negative emotional experiences. Journal of Personality \& Social Psychology, 86(2), 320-333. https://doi.org/10.1037/0022-3514.86.2.320

Urbach, N. \& Ahlemann, F. (2010). Structural equation modelling in information system research using partial least square. Journal of Information Technology: Theory and Application, 11(2), 5-40.

Wagnild, G. M. \& Young, H. M. (1993). Development and psychometric evaluation of the resilience scale. Journal of Nursing Measurement, 1(2), 165-178.

Walker, B. H., Gunderson, L. H, Kinzig, A. P., Folke, C., Carpenter, S. R. \& Schultz. L. (2006). A handful of heuristics and some propositions for understanding resilience in social-ecological systems. Ecology and Society, 11(1), 13. https://doi.org/10.5751/ES-01530-110113

White, B., Driver, S. \& Warren, A. M. (2010). Resilience and indicators of adjustment during rehabilitation from a spinal cord injury. Rehabilitation Psychology, 55(1), 23-32. https://doi.org/10.1037/a0018451

Yusoff, M. S. B. (2013). Associations of pass-fail outcomes with psychological health of first year medical students in a Malaysian medical school. Sultan Qaboos University Medical Journal, 13(1), 107-114. https://doi.org/10.12816/0003203

Zautra, A. J., Hall, J.S. \& Murray, K. E. (2010). Resilience: A new definition of health for people and communities. In J. R. Reich, A. J. Zautra, \& J.S. Hall (Eds.). Handbook of Adult Resilience, 3-30. New York: Guilford. 